\title{
Effect of Chronic Infusion of Cortisol on Renin Gene Expression and Renin Response to Hemorrhage in Fetal Lambs
}

\author{
GIUSEPPINA M. R. CARBONE, ASAD U. SHEIKH, TIM ZEHNDER, AND JAMES C. ROSE
}

Departments of Physiology and Pharmacology and Obstetrics and Gynecology and Perinatal Research Laboratories, Bowman Gray School of Medicine, Wake Forest University,

Winston-Salem, North Carolina 27157

\begin{abstract}
In the ovine fetus, plasma renin levels increase close to term, and renin responses to various stimuli are enhanced when compared with responses earlier in gestation. These changes are accompanied by increases in renal renin gene expression and renin content, and they occur in conjunction with elevations in fetal plasma cortisol. Thus, the purpose of this study was to test the hypothesis that a chronic, physiologic elevation in fetal plasma cortisol in early gestation would increase activity in the renin-angiotensin system prematurely. We studied fetuses (control, $n=8$; cortisol infused, $n=11$ ) at $94 \pm 2 \mathrm{~d}$ of gestation. Fetal vessels were catheterized, and cortisol or saline solution was infused for $6 \mathrm{~d}$. At the end of infusion, fetuses were hemorrhaged approximately $30 \%$ of estimated blood volume.
\end{abstract}

\section{ABSTRACT}

Blood samples were collected to measure plasma renin concentration. Then the animals were killed, and kidneys were removed to measure renin mRNA and renin content. Plasma cortisol concentrations in the control and cortisol-treated animals were $7.2 \pm 0.8$ and $57.7 \pm 8.6 \mathrm{nmol} / \mathrm{L}(p<0.01)$, respectively. Basal plasma renin concentrations were similar in the two groups $3.2 \pm$ 0.4 versus $4.4 \pm 1.8 \mathrm{ng}$ of angiotensin $\mathrm{I} / \mathrm{mL} / \mathrm{h}$, and there was a significant increase after hemorrhage in the cortisol-treated group only. Renal renin content and mRNA levels were similar in the two groups. These data indicate that chronic increases in cortisol in fetal lambs at 0.65 gestation significantly enhance the renin response to hemorrhage but do not alter renal renin gene expression. (Pediatr Res 37: 316-320, 1995)
The renin-angiotensin system undergoes marked maturational changes during development. Renin responsiveness to several physiologic and pharmacologic stimuli is greater in late-gestation fetuses than in fetuses earlier in the third trimester $(1,2)$. In addition, renin mRNA levels significantly increase between 0.65 and 0.96 gestation, and a parallel increase in renal renin content also occurs (3). These findings indicate that in the perinatal period there is an activation of renin gene expression that is determined at least in part by events at the transcriptional level. The observed increase in renin gene expression is temporally associated with a pronounced and prolonged elevation in fetal plasma cortisol (4). Moreover, in the regulatory region of the human, rat, and mouse, renin gene glucocorticoid-responsive elements have been described (5). Therefore, in the present study, we investigated the possibility that cortisol plays a role in the activation of renin gene expression in fetal lambs. We hypothesized that chronic exposure of early-gestation fetuses (between 94 and $103 \mathrm{~d}$ of gestation) to cortisol levels similar to those observed in late gestation fetal lambs would cause a premature increase in renin

Received March 7, 1994; accepted November 17, 1994.

Correspondence: James C. Rose, Ph.D., Department of Physiology and Pharmacology, Bowman Gray School of Medicine, Winston-Salem, NC 27157.

Supported by Grant HD17644 from the National Institutes of Health. gene expression as well as an enhancement of the renin response to hemorrhage.

\section{METHODS}

\section{Animal Preparation and Infusion}

Nineteen time-dated pregnant sheep were studied between 94 and $103 \mathrm{~d}$ of gestation (term, $145 \mathrm{~d}$ ). Surgery was performed at $94 \pm 1 \mathrm{~d}$ of gestation. The surgical procedure has been previously described (6). Briefly, catheters were placed bilaterally in fetal femoral arteries (for blood collection and cardiovascular measurements) and veins (for infusion). Sheep were randomly assigned to one of two groups: vehicle or cortisol. One day after surgery the fetuses began receiving 6-d i.v. infusions of either vehicle $(n=8)$ or $0.86 \mu \mathrm{g} / \mathrm{min} / \mathrm{kg}$ cortisol $(n=11)$. To maintain a constant level of infusion, the dose of cortisol administered was adjusted daily based on an assumed fetal growth rate of $4 \% / \mathrm{d}$. Arterial blood was collected on $\mathrm{d} 2,4$, and 6 for the measurement of plasma cortisol and blood gasses.

Hemorrhage and tissue collection. On the sixth day of infusion, $30 \%$ of the fetal estimated blood volume was withdrawn at a rate of $3 \mathrm{~mL} / \mathrm{min}$ into three $10-\mathrm{mL}$ syringes during $10 \mathrm{~min}$. Blood from the first syringe was considered control, 
whereas that obtained from the third syringe contained the hemorrhage sample. Fetal weight was estimated at the time of surgery, based on the data of Jobert (7), and blood volume was estimated as $110 \mathrm{~mL} / \mathrm{kg}$ fetal weight (8). Mean arterial pressure and heart rate were recorded on a polygraph (Hewlett Packard, Palo Alto, CA) and stored on disk using an IBM AT computer and an appropriate analog-to-digital board. After the hemorrhage, the amount of blood removed was replaced by an equivalent volume of saline solution. Animals were killed, and slices of kidney cortex for mRNA and enzyme activity were collected and stored at $-80^{\circ} \mathrm{C}$ until processed. All procedures were approved by our Institutional Animal Care and Use Committee.

\section{Quantification of Renin mRNA}

Total RNA extraction. The total RNA was extracted from kidneys of fetuses receiving vehicle $(n=6)$ and cortisol $(n=$ 6) using a modified acid-guanidinium procedure (9). Tissue slices were homogenized $(100 \mathrm{mg} / \mathrm{mL})$ in RNA extraction buffer ( $4 \mathrm{M}$ guanidinium thiocyanate, $25 \mathrm{mM}$ sodium citrate, $\mathrm{pH} 7.0,0.5 \%$ sarcosyl, and $0.1 \mathrm{M} \beta$-mercaptoethanol) with a Polytron homogenizer (Brinkmann Instruments, Westbury, NY) at setting 6 for $30 \mathrm{~s}$. After homogenization, $50 \mu \mathrm{L}$ of $2 \mathrm{M}$ sodium acetate, $\mathrm{pH} 4.0,500 \mu \mathrm{L}$ of water-saturated phenol, and $100 \mu \mathrm{L}$ of chloroform-isoamyl alcohol (49:1) were added. After this, the samples were centrifuged for $3 \mathrm{~min}$ at $14000 \times$ $g$, and 1 volume of ice-cold isopropanol was added to the aqueous phase. After incubation at $-80^{\circ} \mathrm{C}$ for $15 \mathrm{~min}$, samples were centrifuged for $10 \mathrm{~min}$. The resulting pellets were dissolved in $500 \mu \mathrm{L}$ of RNA extraction buffer, reprecipitated with the same volume of isopropanol for $15 \mathrm{~min}$ at $-80^{\circ} \mathrm{C}$, and centrifuged for $10 \mathrm{~min}$. The pellets were then washed twice with cold $75 \%$ ethanol, dried, and resuspended in water that had been treated with diethylpyrocarbonate. The RNA concentration was determined by absorbance at $260 \mathrm{~nm}$.

Dot-blot analysis. Aliquots of total RNA (15-20 $\mu \mathrm{g})$ from the kidney cortex of each animal were diluted with diethylpyrocarbonate-treated water $(50 \mu \mathrm{L}), 20 \times$ standard saline citrate (30 $\mu \mathrm{L})$, and $37 \%$ formaldehyde $(20 \mu \mathrm{L})$, denatured at $65^{\circ} \mathrm{C}$ and serially diluted with $15 \times$ standard saline citrate, and applied to nylon using a mini-dot-blot apparatus. The serial dilutions of the dot blots were prehybridized for $4 \mathrm{~h}$ at $65^{\circ} \mathrm{C}$ with $0.5 \mathrm{M}$ sodium phosphate buffer $(\mathrm{pH} 7)$ containing $7 \%$ SDS, $1 \mathrm{mM}$ EDTA, denatured salmon sperm DNA $(100 \mu \mathrm{g} /$ $\mathrm{mL})$ and transfer RNA $(10 \mu \mathrm{g} / \mathrm{mL})$ and then hybridized with the same buffer with the addition of $4 \times 10^{6} \mathrm{cpm} / \mathrm{mL}\left[{ }^{32} \mathrm{P}\right] \mathrm{re}-$ nin cDNA probe. After overnight hybridization, the filter was washed at $65^{\circ} \mathrm{C}$ five times for $10 \mathrm{~min}$ each in a buffer containing $0.1 \mathrm{M}$ EDTA, $1 \% \mathrm{SDS}$, and $40 \mathrm{mM} \mathrm{NaH}_{2} \mathrm{PO}_{4}, \mathrm{pH} 6.8$ (10). After autoradiography, the renin probe was stripped and the filter rehybridized with the $\left[{ }^{32} \mathrm{P}\right] \beta$-actin probe for control.

Data analysis. After autoradiography, the intensity on all dot-blot autoradiograms was measured by optical densitometry recorded on a laser densitometer. Two measurements of signal intensity at different exposure times were obtained for each sample. To correct for any variation in RNA blotted on the nylon, the densitometric signals obtained from the $\beta$-actin were quantified, and results from the renin signal were expressed relative to the $\beta$-actin signal. Duplicate samples of total RNA from each animal were analyzed for renin and $\beta$-actin, and results were expressed as the average of the two measurements.

Probe preparation. A full-length cDNA probe for rat kidney renin was generously provided by Dr. Kevin Lynch (University of Virginia, Charlottesville, VA). The cDNA probe was obtained by random priming in the presence of $\left[{ }^{32} \mathrm{P}\right]$ deoxy-ATP as labeled nucleotide using the procedure of Feinberg and Vogelstein (11).

A 770-bp cDNA from chicken $\beta$-actin was obtained from Oncor (Gaithersburg, MD) and labeled with the randompriming method as described above (11).

\section{Hormone Measurements}

Plasma renin concentration. Plasma samples were collected in test tubes containing EDTA. Red cells were separated, and plasma was stored frozen until processed. Plasma renin concentration was measured using commercially available reagents (Biotex Laboratories, Inc., Friendswood, TX) as nanograms of angiotensin I generated per $\mathrm{mL} / \mathrm{h}$ in presence of excess of substrate. The source of substrate was plasma from a nephrectomized ewe. This plasma had an excess of substrate and undetectable renin levels. All samples from the same animal were measured in the same assay.

Renal renin concentration. The renal renin content was measured as previously described (12). The tissue was homogenized with a 5-mL tapered glass homogenizer (Bellco, Vineland, NJ) and cold $\left(4^{\circ} \mathrm{C}\right)$ neutral $(\mathrm{pH} 7.4)$ buffer solution containing $15 \mathrm{mM}$ disodium EDTA, $5 \mathrm{mM}$ dimercaprol, and $3.5 \mathrm{mM}$ 8-hydroxyquinoline $(0.1 \mathrm{mg} / 5 \mathrm{~mL})$; these agents inhibit protease activity. The homogenate was spun in a refrigerated $\left(4^{\circ} \mathrm{C}\right)$ centrifuge at $1000 \times g$ for $10 \mathrm{~min}$. The supernatant was collected and further diluted with the homogenization buffer at $1 \mathrm{~mL} / 1 \mathrm{mg}$ wet weight of tissue. A $150-\mu \mathrm{L}$ aliquot of the sample was added to $850 \mu \mathrm{L}$ of renin substrate. After $2 \mathrm{~h}$ of incubation at $37^{\circ} \mathrm{C}$, the renal concentration of active renin was determined by measuring angiotensin I generation. The results for renin content of the homogenate were calculated and expressed as nanograms of angiotensin I per $\mathrm{mg} / \mathrm{h}$. The source of substrate was plasma from a nephrectomized ewe, as described above. All samples were measured in the same assay.

Cortisol concentration. Cortisol was measured by RIA. Details have been described previously (13).

\section{Analysis of Results}

Statistics. The data are reported as mean \pm SEM. All data were analyzed by analysis of variance followed by the Newman-Keuls test where appropriate (14). Differences were considered significant at $p<0.05$.

\section{RESULTS}

The plasma cortisol concentration was significantly greater in fetuses receiving cortisol than vehicle (Fig. 1). Table 1 shows mean gestational ages, body and kidney weights, and hematocrits on the day of killing. Fetal and kidney weights 


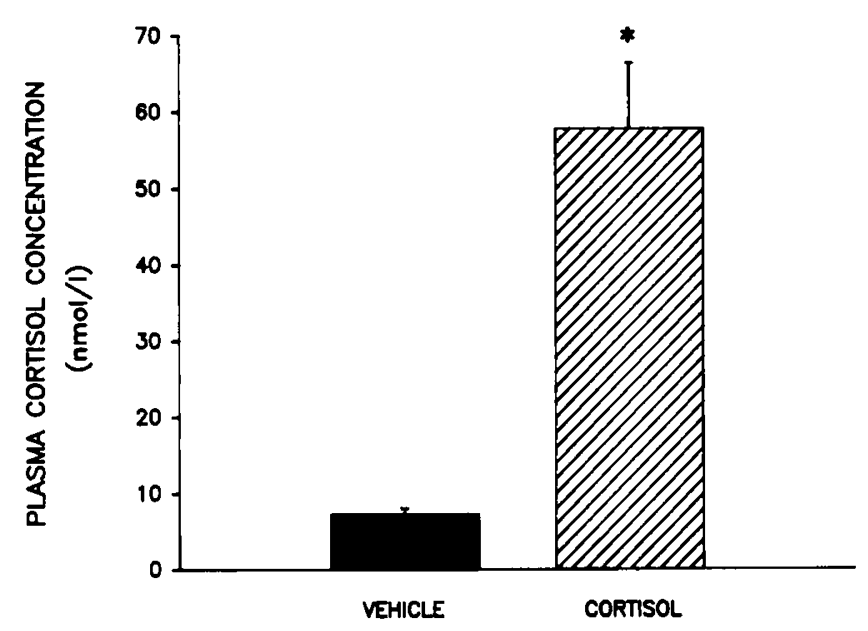

Figure 1. Plasma cortisol concentration in fetuses receiving vehicle and cortisol. Values represent mean \pm SEM of values observed at 2,4 , and $6 \mathrm{~d}$ of infusion. Cortisol concentration was significantly higher in the group receiving cortisol $(p<0.0001)$.

Table 1. Data from vehicle- and cortisol-treated animals on day of hemorrhage

\begin{tabular}{lcc}
\hline & Vehicle-treated & Cortisol-treated \\
\hline Gestational age (d) & $100.5 \pm 0.7$ & $100.8 \pm 0.7$ \\
Body wt (kg) & $1.1 \pm 0.0$ & $1.1 \pm 0.0$ \\
Kidney wt (g) & $5.0 \pm 0.0$ & $5.0 \pm 0.0$ \\
Hematocrit (\% packed cells) & $32.0 \pm 2.0$ & $30.0 \pm 1.0$ \\
\hline
\end{tabular}

were similar in both groups. The hematocrit was also similar in both groups. Relative levels of renal renin mRNA were not different between groups (Fig. 2). Renal renin content was similar in the cortisol group and the control group (Fig. 3). The renal renin content values were similar to those previously observed in noninstrumented fetal lambs $(3,11)$. Basal plasma renin levels were $3.2 \pm 0.4$ and $4.4 \pm 1.8 \mathrm{ng}$ of angiotensin I per $\mathrm{mL} / \mathrm{h}$ in the two groups.

Resting mean arterial pressure, blood gases, and $\mathrm{pH}$ were similar in the two groups (Table 2). Hemorrhage caused a significant decrease in mean arterial pressure and $\mathrm{Po}_{2}$ and an

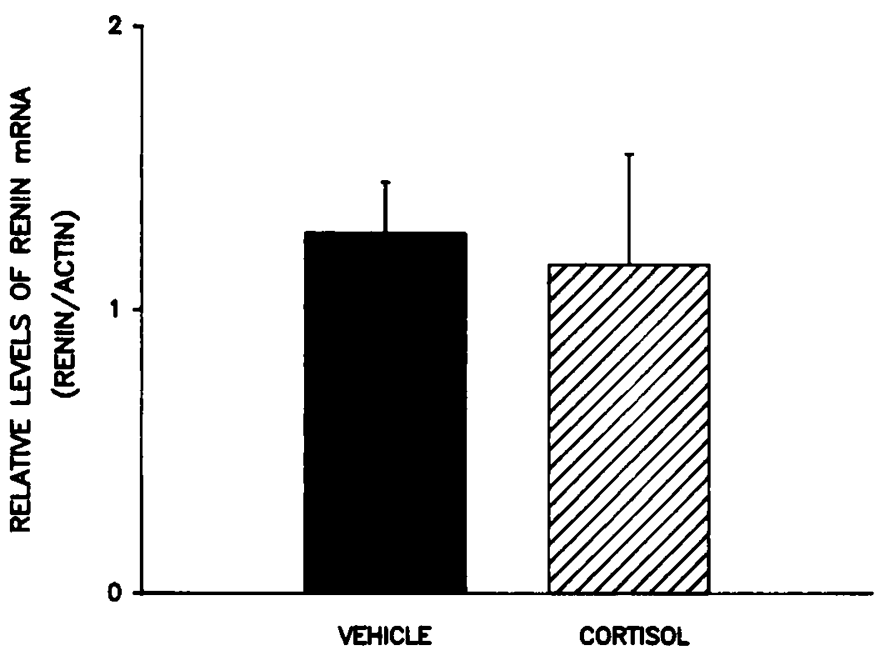

Figure 2. Relative levels of renal renin mRNA evaluated by dot-blot technique and densitometric analysis of the autoradiograms. Values represent mean \pm SEM of the ratio of renin to $\beta$-actin densitometric units from fetuses receiving vehicle and cortisol.

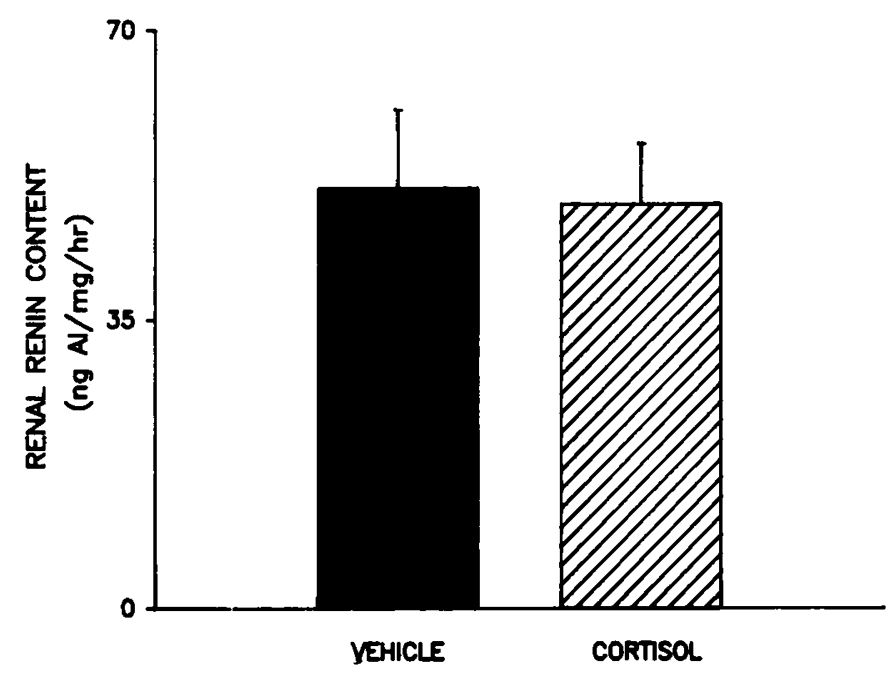

Figure 3. Renal renin content (nanograms of angiotensin $\mathrm{I}$ per $\mathrm{mg} / \mathrm{h}$ ). Values represent mean $\pm S E M$ of level in fetuses receiving vehicle and cortisol.

increase in $\mathrm{PCO}_{2}$ in both groups. The changes were similar in the control and cortisol-treated animals (Table 2). Figure 4 shows the changes in renin concentration after hemorrhage in control and cortisol-treated animals at 5 and $10 \mathrm{~min}$ after the stimulus. The renin response to hemorrhage was different in the two groups $(F=5.01 ; p<0.04)$ with a significant increase present in the cortisol-treated animals $(F=5.7 ; p<0.03)$. One-way analysis of variance of both groups also revealed an increase in renin in the cortisol-treated group only $(F=7.6$; $p<0.02)$.

\section{DISCUSSION}

In the present study, we tested the possibility that chronic increases in cortisol to levels similar to those observed at 0.85 gestation would activate renin gene expression and the renin response to hemorrhage in fetal lambs at 0.65 gestation. Our data indicate that maintaining such an increase in the plasma concentration of cortisol for $6 \mathrm{~d}$ increases the renin response to hemorrhage but does not increase renin gene expression. Thus, an increase in renin responsiveness to acute stimulation may occur without an increase in renal renin mRNA and renal renin content in the immature fetus.

The mechanism by which cortisol modulates the renin response to hemorrhage is unknown but may be related to enhancement of renin secretion mediated by sympathetic activity. Numerous studies in adults have shown that renin secretion is stimulated by increased renal nerve activity (15). The renal nerves also influence renin secretion in the fetus close to term (16). Renin secretion mediated by renal nerve activity is a $\beta$-adrenergic effect (15). This $\beta$-adrenergic effect is brought about by activation of adenylate cyclase and an increase in cAMP in juxtaglomerular cells (17). Although the $\beta$-receptor mechanisms modulating renin secretion seem immature in early gestation $(12,18)$, corticosteroids have pronounced effects on $\beta$-receptors and adenylate cyclase activity during development. For example, in fetal rabbits and rats, corticosteroids increase $\beta$-receptor number in the lungs (19, 20). Also, in fetal sheep, at approximately 0.75 gestation, 
Table 2. Effects of hemorrhage on blood gases, pH, and blood pressure in vehicle- and cortisol-treated animals

\begin{tabular}{lcccr} 
& \multicolumn{2}{c}{ Vehicle-treated } & \multicolumn{2}{c}{ Cortisol-treated } \\
\cline { 2 - 5 } & Control & Hemorrhage & Control & Hemorrhage \\
\hline $\mathrm{Po}_{2}(\mathrm{kPa})$ & $2.9 \pm 0.1$ & $2.3 \pm 0.1^{*}$ & $3.0 \pm 0.1$ & $2.5 \pm 0.1^{*}$ \\
$\mathrm{PCO}_{2}(\mathrm{kPa})$ & $6.3 \pm 0.2$ & $6.9 \pm 0.1^{*}$ & $6.3 \pm 0.2$ & $6.6 \pm 0.2^{*}$ \\
$\mathrm{pH}$ & $7.34 \pm 0.01$ & $7.34 \pm 0.01$ & $7.36 \pm 0.01$ & $7.36 \pm 0.01$ \\
$\mathrm{Blood}$ pressure $(\mathrm{kPa})$ & $5.3 \pm 0.3$ & $4.0 \pm 0.3^{*}$ & $5.2 \pm 0.1$ & $3.9 \pm 0.2^{*}$ \\
\hline
\end{tabular}

${ }^{*} p<0.05$ vs control.

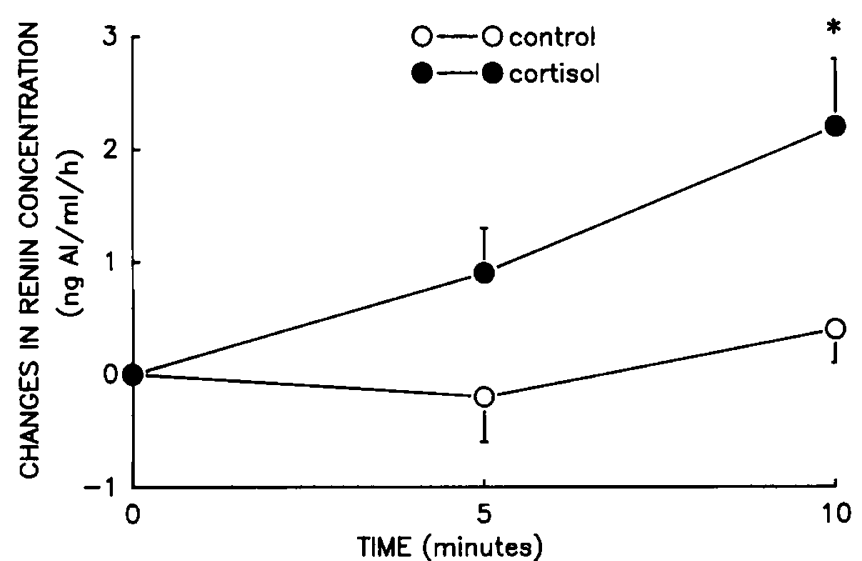

Figure 4. Changes in plasma renin concentration after acute hemorrhage in fetuses receiving vehicle and cortisol. The renin response to hemorrhage was significant only in the group receiving cortisol $(p<0.04)$.

corticosteroid treatment increases isoproterenol-sensitive myocardial adenylate cyclase activity (21). Thus, the enhanced renin response to hemorrhage after chronic cortisol treatment in these immature fetuses may reflect a steroid-induced increase in $\beta$-receptor number or improved coupling of $\beta$-receptors, adenylate cyclase activity, and cAMP generation in the fetal kidney.

Pretreatment with corticosteroids also potentiates the effects of PTH on cAMP generation in bone cells. This potentiation is the result of inhibition of phosphodiesterase activity $(22,23)$. Large doses of steroids also inhibit phosphodiesterase activity in testicular and myocardial tissue (24). A similar mechanism may be at work in the fetal kidney after prolonged exposure to increased levels of cortisol. If phosphodiesterase activity is inhibited in the fetal kidney, then the cAMP response to adrenergic stimulation would be enhanced, and an increase in renin release would be seen after hemorrhage.

Finally, cortisol has been shown to inhibit the uptake 2 mechanism responsible for removal and degradation of catecholamines by postsynaptic tissue (25). This effect, if present in the fetal kidney, would potentiate the secretion of renin induced by catecholamines released from the renal nerves and thereby enhance the renin response to hemorrhage.

Alternatively, there is abundant evidence that renin secretion is influenced by an intrarenal baroreceptor in adult animals (15). This baroreceptor in the kidney is functional in pregnant and nonpregnant sheep. Thus, reductions in renal perfusion pressure stimulate renin secretion (26). In late gestation fetal lambs, acute reductions in renal perfusion pressure also activate the renal baroreceptor and increase renin secretion (27). It is possible that the cortisol treatment of the fetuses in this study increased the threshold for renal baroreceptor activation such that the hemorrhage-induced fall in arterial blood pressure (renal perfusion pressure) was an adequate stimulus for renin secretion at 94-103 d of gestation. The mechanisms by which cortisol could alter renal baroreceptor function are unclear at present.

Short-term infusions of cortisol in late gestation have been reported to have variable effects on fetal plasma renin activity and renin concentration $(28,29)$. The differences between those results and the present data may be related to differences in the gestational ages of the animals studied or the duration of the elevation in plasma cortisol.

There is disagreement in the literature concerning the effects of cortisol on fetal blood pressure and heart rate. Elevations in cortisol have been reported to have no effect on arterial pressure and heart rate in late gestation (30) or to increase blood pressure and decrease heart rate (31). In less-mature fetuses (103-120 d of gestation), increases in cortisol lasting $24 \mathrm{~h}$ seem to increase fetal blood pressure and the blood pressure response to injections of angiotensin (30). Our results do not reveal a significant effect of cortisol on blood pressure or heart rate in immature fetuses. This lack of an effect may result from an inability of cortisol to alter vascular responsiveness to vasoconstrictors before $100 \mathrm{~d}$ of gestation. Tangalakis et al. (30) have observed that cortisol treatment enhances blood pressure increases after angiotensin administration at approximately $120 \mathrm{~d}$ of gestation. These observations suggest that cortisol might modulate vascular responsiveness only at certain times in development.

Our data suggest that the elevation in fetal plasma cortisol occurring in late gestation is not the sole cause of the increase in renal renin content and renin mRNA normally seen at this time. However, our observation that cortisol did not increase renin expression in the fetal kidney must be interpreted with some caution. Any effect of cortisol on renin expression may require the presence of transcription factors, which appear late in gestation (32). In their absence, the effect of cortisol would be minimal. Some support for this possibility is found in the work of Nogami and Tachibana (33). These authors found that dexamethasone could induce growth hormone mRNA and protein expression in fetal rats on d 18 or 19 of gestation but not on d 16. Similarly, cortisol induces antioxidant enzyme activity in late but not early gestation (34). Thus, infusions of cortisol in late gestation could have different effects on renin expression than those we observed in early gestation. This possibility awaits further investigation.

\section{REFERENCES}

1. Robillard JE, Weitzman RE, Burmeister L, Smith FG Jr 1981 Developmental aspects of the renal response to hypoxemia in the lamb fetus. Circ Res 48:128-138 
2. Rawashdeh N, Rose JC, Ray ND 1988 Differential maturation of beta-adrenoceptor responses in the lamb fetus. Am J Physiol 255:R794-R798

3. Carbone GMR, Sheikh AU, Rogers S, Brewer G, Rose JC 1993 Developmental changes in renin gene expression in ovine kidney cortex. Am J Physiol 264:R591R596

4. Rose JC, Kerr DR 1992 Development of the corticotropin-releasing factor ACTH/ beta endorphin system in the mammalian fetus. In: Polin RA, Fox WW (eds) Fetal and Neonatal Physiology. WB Saunders, Philadelphia, pp 1806-1814

5. Burt DW, Nakamura N, Kelley P, Dzau V 1989 Identification of negative and positive regulatory elements in the human renin gene. J Biol Chem 264:7357-7362

6. Rose JC, MacDonald AA, Heymann MA, Rudolph AM 1978 Developmental aspects of the pituitary-adrenal responses to hemorrhagic stress in lamb fetuses in utero. $\mathrm{J}$ Clin Invest 61:424-432

7. Jobert DM 1956 A study of prenatal growth and development in the sheep. J Agricultural Sci 47:382-427

8. Brace RA 1983 Blood volume and its measurement in the chronically catheterized sheep fetus. Am J Physiol 244:H487-H494

9. Chomiczynsky P, Sacchi N 1987 Single step method of RNA isolation by acid guanidium thiocyanate-phenol-chloroform extraction. Anal Biochem 162:156-159

10. Church GM, Gilbert W 1984 Genomic sequencing. Proc Natl Acad Sci USA 81:1991

11. Feinberg AP, Vogelstein B 1983 A technique for radiolabeling DNA restriction endonuclease fragments to high specific activity. Anal Biochem 132:6-13

12. Rawashdeh NM, Rose JC, Kerr DR 1991 Age-dependent differences in active and inactive renin in the lamb fetus. Biol Neonate 60:243-248

13. Rose JC, Meis PJ, Morris M 1981 Ontogeny of endocrine (ACTH, vasopressin, cortisol) responses to hypotension in lamb fetuses. Am J Physiol 240:E656-E661

14. Zar JH 1984 Biostatistical Analysis. Prentice Hall, Engelwood Cliffs, NJ, pp 185-191

15. Hackenthal E, Paul M, Ganten D, Taugner R 1990 Morphology, physiology, and molecular biology of renin secretion. Physiol Rev 70:1067-1116

16. Page WV, Perlman S, Smith FG, Segar JL, Robillard JE 1992 Renal nerves modulate kidney renin gene expression during the transition from fetal to newborn life. Am J Physiol 262:R459-R463

17. Kurtz A, Scholz H, della Bruan R 1990 Molecular mechanisms of renin release. J Cardiovasc Pharmacol 16:S1-S7

18. Nakamura KT, Page WV, Sato T, Klinkefus JM, Robillard JE 1989 Ontogeny of isoproterenol-stimulated renin secretion from sheep renal cortical slices. Am J Physiol R1258-R1263

19. Cheng JB, Goldfien A, Ballard P, Robberts JM 1980 Glucocorticoids increase pulmonary $\beta$-adrenergic receptors in fetal rabbit. Endocrinology 107:1646-1648
20. Mano KA, Akbarzadeh A, Townley RG 1979 Effect of hydrocortisone on betaadrenergic receptcrs in lung membranes. Life Sci 25:1925-1930

21. Stein HM, Oyama K, Martinez A, Cappell BA, Buhl E, Blount L, Padbury JF 1993 Effects of corticcisteroids in preterm sheep on adaptation and sympathoadrenal mechanisms at birth. Am J Physiol 264:E763-E769

22. Chen T, Feldman D 1978 Glucocorticoid potentiation of adenosine $3^{\prime}, 5^{\prime}$ monophosphate response to parathyroid hormone in cultured rat bone cells. Endocrinology 102:589-596

23. $\mathrm{Ng} \mathrm{B}$, Hekkelman JW, Heersche JNM 1979 The effect of cortisol on the adenosine $3^{\prime}, 5^{\prime}$-monophosphate response to parathyroid hormone of bone in vitro. Endocrinology $104: 1130-1135$

24. Schmidtke J, Wienker T, Flugel M, Engel W 1976 In vitro inhibition of cyclic AMP phosphodiesterase by cortisol. Nature 262:593-595

25. Pun LG, McCulloch MW, Rand MJ 1973 The effect of hydrocortisone on the bronchodilator activity of sympathomimetic amines and on the uptake of isoprenaline in the isolated guinea pig trachea. Eur J Pharmacol 22:162-169

26. Fan L, Archambault D, Chavez S, Aljabari AW, Quillen EW Jr 1994 Influences of renal nerves and pregnancy on renin secretion in sheep. Am J Physiol 266:R668R673

27. Binder ND, Anderson DF 1992 Plasma renin activity responses to graded decreases in renal perfusior pressure in fetal and newborn lambs. Am J Physiol 262:R524R529

28. Wood CE, Keil L, Rudolph AM 1984 Physiological inhibition of ovine fetal plasma renin activity by cortisol. Endocrinology 115:1792-1796

29. Wood CE 1986 Sensitivity of cortisol-induced inhibition of ACTH and renin in fetal sheep. Am J Physiol 250:R795-R802

30. Tangalakis K, Lumbers ER, Moritz KM, Towstoless MK, Wintour EM 1992 Effect of cortisol on blood pressure and vascular reactivity in the ovine fetus. Exp Physiol 77:709-717

31. Wood CE, Cheung CC, Brace RA 1987 Fetal heart rate, arterial pressure, and blood volume responses to cortisol infusion. Am J Physiol 253:R904-R909

32. Nitsch D, Boshart M, Schutz G 1993 Activation of tyrosine aminotransferase gene is dependent on synergy between liver-specific and hormone response elements. Proc Natl Acad Sci USiA 90:5479-5483

33. Nogami H, Tach bana T 1993 Dexamethasone induces advanced growth hormone expression in the fetal rat pituitary gland in vivo. Endocrinology 132:517-523

34. Frank L, Lewis PL, Sosenko IRS 1985 Dexamethasone stimulation of fetal rat lung antioxidant enzyne activity in parallel with surfactant stimulation. Pediatrics 75:569574 